\title{
Purification and Some Properties of Bilirubin Oxidase of Myrothecium verrucaria MT-1
}

\author{
Noriaki TANAKa and Sawao Murao \\ Department of Agricultural Chemistry, College of Agriculture, \\ University of Osaka Prefecture, Sakai, Osaka 591, Japan
}

Received March 16, 1982

\begin{abstract}
Bilirubin oxidase was purified from the culture filtrate of Myrothecium verrucaria MT-1 by a procedure involving ammonium sulfate precipitation, charcoal treatment, and QAE-Sephadex A50 and Sephadex G-100 column chromatographies. The purified enzyme was homogeneous on disc gel electrophoresis.

Copper and carbohydrate were contained in the enzyme. The enzyme was inhibited by $\mathrm{Fe}^{2+}$ and compounds that complex with copper. Bilirubin, biliverdin, hemin and chlorophyllin which consist of tetrapyrrole, and substrates of laccase were oxidized by the enzyme. Bilirubin was oxidized more rapidly than other substances. Bilirubin oxidase differed from laccase in reactivity with substances consisting of tetrapyrrole. Substances consisting of tetrapyrrole were oxidized only a little by laccase but rapidly oxidized by bilirubin oxidase. The apparent $\mathrm{Km}$ value for bilirubin was calculated to be $190 \mu \mathrm{M}$.
\end{abstract}

In the previous communications, ${ }^{1,2)}$ we reported the isolation and classification of a bilirubin oxidase producing microorganism and some properties of the enzyme were also reported. From taxonomic studies, the strain was identified as Myrothecium verrucaria. Bilirubin oxidase was produced in a high yield in potato-glucose medium at $25^{\circ} \mathrm{C}$ for $62 \mathrm{hr}$ in a jar fermentor. It was found that strains belonging to the genus Myrothecium also produced bilirubin oxidase. In the present paper, the purification and some properties of bilirubin oxidase from Myrothecium verrucaria MT-1 are reported.

\section{MATERIALS AND METHODS}

Chemicals. All chemicals used in this work were commercial products.

Microorganism and cultural conditions. The microorganism used was Myrothecium verrucaria MT-1 which had been isolated from soil. ${ }^{1,2)}$ The medium and cultural conditions used for the production were described in the previous paper. ${ }^{2)}$

Enzyme assay. Bilirubin oxidase activity was assayed by the method described in the previous paper. ${ }^{1)}$ The specific activity was expressed as the enzyme activity per $\mathrm{mg}$ protein.

Assay of protein. Protein concentration was determined spectrophotometrically assuming that $E_{1 \mathrm{~cm}}^{1 \%}$ at $280 \mathrm{~nm}$ was 10.0 .

Polyacrylamide gel electrophoresis. Disc gel electrophoresis was carried out at $\mathrm{pH} 9.5 .{ }^{3)}$ A sample was applied on the top of the stacking gel and run at a constant current of $3 \mathrm{~mA}$ per tube for $1 \mathrm{hr}$. Staining of the gel was carried out using Coomassie Brilliant Blue for detecting protein bands and periodic acid-Schiff (PAS) for glycoprotein bands. $^{4)}$

Isoelectric focusing. Isoelectric focusing analyses were performed according to the method of Vesterberg and Svensson. ${ }^{5}$ A sample of the enzyme protein was applied to a column of carrier ampholytes with a $\mathrm{pH}$ range of $3.5 \sim 5.0$. Constant potentials, $300 \mathrm{~V}$ for the first $3 \mathrm{hr}$ and $700 \mathrm{~V}$ for the following $40 \mathrm{hr}$, were applied to the column at $0^{\circ} \mathrm{C}$ and the column was drained and fractionated into $2 \mathrm{ml}$ fractions.

Determination of molecular weight by gel filtration. Gel filtration was performed using Sephadex G-100 $(2.5 \times 92 \mathrm{~cm})$ following the method of Andrews. $\left.{ }^{6}\right)$ Sephadex G-100 (Pharmacia) was equilibrated with $0.03 \mathrm{M}$ $\mathrm{Na}_{2} \mathrm{CO}_{3}-\mathrm{NaHCO}_{3}$ buffer (pH 9.3) containing $0.1 \mathrm{M} \mathrm{NaCl}$. Cytochrome $c$, ovalbumin and bovine serum albumin were 


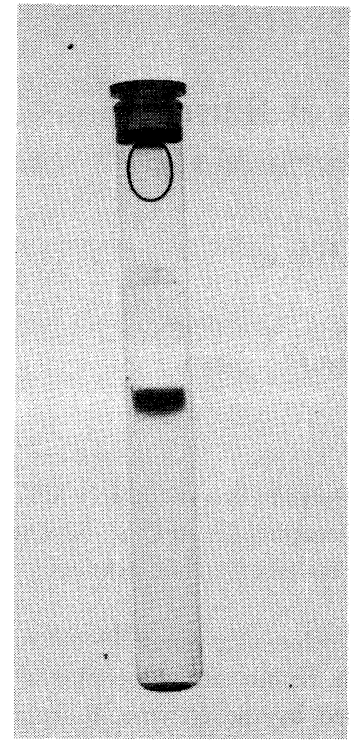

FIG. 1. Polyacrylamide Gel Disc Electrophoresis of Laccase.

Electrophoresis was carried out using 7\% gel at $\mathrm{pH}$ 8.0. The protein (about $20 \mu \mathrm{g}$ ) was stained with Coomassie Brilliant Blue.

used as the reference proteins.

Amino acid composition. Purified enzyme protein was hydrolyzed with $6.0 \mathrm{~N} \mathrm{HCl}$ at $110^{\circ} \mathrm{C}$ in evacuated sealed tubes for 24,48 and $72 \mathrm{hr}$, respectively. The hydrolyzate was rapidly dried in vacuo and then dissolved in $90 \mathrm{~mm}$ citrate buffer $(\mathrm{pH} 2.2)$. Amino acids in this solution were analyzed with a Hitachi KLA-5 amino acid analyser. The amounts of cysteine and tryptophan were determined according to the methods of Moore ${ }^{7)}$ and Goodwin, ${ }^{8)}$ respectively.

Laccase of Polyporus versicolor IFO 9791. Laccase of Polyporus versicolor was obtained by the procedure of Fåhraeus and Reinhammar. ${ }^{9)}$ Homogeneity of the purified enzyme was examined by means of polyacrylamide gel disc electrophoresis. ${ }^{3)}$ As shown in Fig. 1, a single protein band was obtained, so it was regarded as being homogeneous.

\section{RESULTS}

Purification of the enzyme

After the cultivation, the culture broth was centrifuged and the clear supernatant was used as the starting material for the purification.

Step 1. Ammonium sulfate precipitation. To $3,000 \mathrm{ml}$ of the culture supernatant was added $1,820 \mathrm{~g}$ of finely powdered ammonium

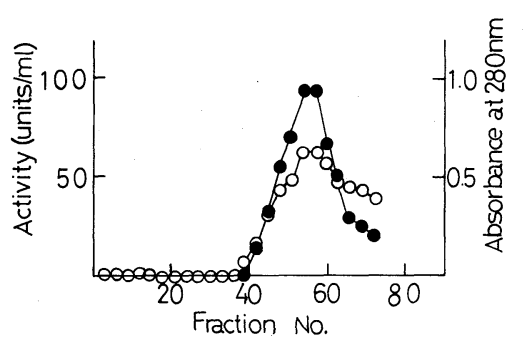

Fig. 2. Elution Pattern of QAE-Sephadex A-50 Column Chromatography.

$13 \mathrm{ml}$ fractions were collected. $\bigcirc-\bigcirc$, absorbance at $280 \mathrm{~nm}$; - - , bilirubin oxidase activity.

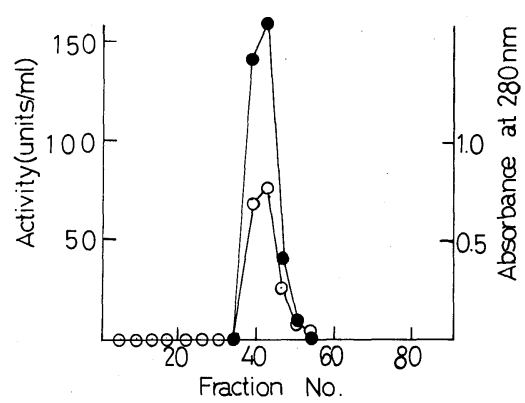

Fig. 3. Elution Pattern of Sephadex G-100 Column Chromatography.

The flow rate was $20 \mathrm{ml}$ per hr and $6.8 \mathrm{ml}$ fractions were collected. $\bigcirc-\bigcirc$, absorbance at $280 \mathrm{~nm} ;-\bigcirc$, bilirubin oxidase activity.

sulfate to $80 \%$ saturation under stirring and the mixture allowed to stand overnight. The precipitates were collected by filtration with Hyflosupercel, dissolved in $400 \mathrm{ml}$ of water and dialyzed against three changes of 10 liters of the $10 \mathrm{~mm} \mathrm{Na} \mathrm{CO}_{3}-\mathrm{NaHCO}_{3}$ buffer ( $\mathrm{pH}$ 9.2) for $24 \mathrm{hr}$ and then clarified by centrifugation.

Step 2. Charcoal treatment. The dialyzed solution was decolorized by treatment with charcoal powder twice $[0.7 \%(\mathrm{w} / \mathrm{v}) \mathrm{pH} 8.8$ and $0.2 \%$ (w/v) $\mathrm{pH} 7.4]$.

Step 3. QAE-Sephadex A-50 column chromatography. The enzyme solution was placed on a QAE-Sephadex A-50 column $(4 \times 15 \mathrm{~cm})$ equilibrated with $15 \mathrm{~mm} \quad \mathrm{Na}_{2} \mathrm{CO}_{3}-\mathrm{NaHCO}_{3}$ buffer ( $\mathrm{pH}$ 9.3). Then the enzyme was eluted with a linear gradient of $\mathrm{Na}_{2} \mathrm{CO}_{3}-\mathrm{NaHCO}_{3}$ buffer of concentrations from $0.015 \mathrm{M}$ to $0.8 \mathrm{M}$. 
The elution pattern of the enzyme is shown in Fig. 2. Active fractions were pooled and concentrated on a Diaflo PM-10 membrane filter.

Srep 4. Gel filtration by Sephadex G-100. The enzyme solution was placed on a Sephadex G-100 column $(2.5 \times 98 \mathrm{~cm})$ equilibrated with $30 \mathrm{~mm} \mathrm{Na} \mathrm{CO}_{3}-\mathrm{NaHCO}_{3}$ buffer ( $\mathrm{pH}$ 9.4). The elution pattern of the enzyme is shown in Fig. 3. The purified enzyme was submitted to polyacrylamide gel electrophoresis. Staining of the gels were carried out with Coomassie Brilliant Blue for detecting protein and periodic acid-Schiff (PAS) for detecting glycoprotein. A single band was obtained $^{1)}$ respectively and the protein band agreed with the glycoprotein band. Bilirubin oxidase was analyzed with an atomic absorption spectroscope and it was found that it possesses about 1 atom of copper per molecule.

\section{Estimation of molecular weight of the enzyme}

From the results shown in Fig. 4, the molecular weight of the enzyme was estimated to be approximately 52,000 .

\section{Isoelectric point}

Electrofocusing with a carrier ampholite ( $\mathrm{pH} 3.5 \sim 5.0$ ) showed that the enzyme has an isoelectric point around $\mathrm{pH} 4.1$.

\section{Amino acid composition}

As shown in Table I, half cystine was not present.

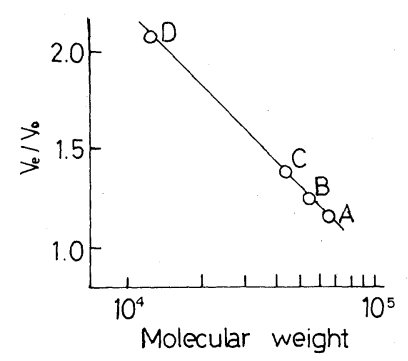

FIG. 4. Estimation of Molecular Weight of the Enzyme by Gel Filtration on Sephadex G-100.

A, bovine serum albumin; B, bilirubin oxidase; $C$, ovalbumin; $\mathrm{D}$, cytochrome $c$.

\section{Stability}

After the purified enzyme was incubated in $0.1 \mathrm{M}$ phosphate buffer, $\mathrm{pH} 8.0$, at various

Table I. Amino Acid Composition of BiliRubin OXIDASE

\begin{tabular}{lc}
\hline Amino acid & Number of residues/molecule \\
\hline Lysine & 7 \\
Histidine & 35 \\
Arginine & 21 \\
Aspartic acid & 56 \\
Threonine & 35 \\
Serine & 21 \\
Glutamic acid & 42 \\
Proline & 35 \\
Glycine & 35 \\
Alanine & 42 \\
1/2 Cystine & 0 \\
Valine & 35 \\
Methionine & 7 \\
Isoleucine & 14 \\
Leucine & 28 \\
Tyrosine & 21 \\
Phenylalanine & 28 \\
Tryptophan & 14 \\
Total & 476 \\
\hline
\end{tabular}

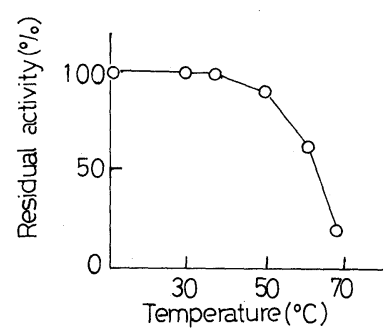

FIG. 5. Effect of Temperature on Stability of the Enzyme.

After treatment at various temperatures for $15 \mathrm{~min}$ at $\mathrm{pH}$ 8.0 , the remaining activity was measured.

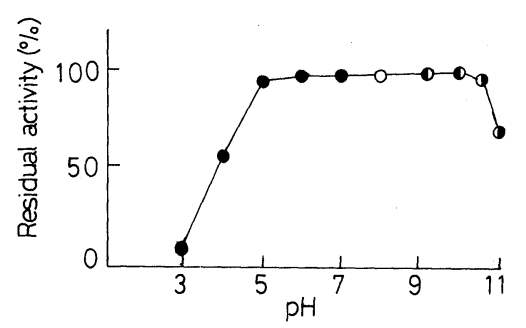

FIG. 6. Effect of $\mathrm{pH}$ on Stability of the Enzyme.

The enzyme, in $0.1 \mathrm{M}$ McIlvaine (O), sodium phosphate (O), $\mathrm{Na}_{2} \mathrm{CO}_{3}-\mathrm{NaHCO}_{3}$ (O), and $\mathrm{Na}_{2} \mathrm{~B}_{4} \mathrm{O}_{7}-\mathrm{Na}_{2} \mathrm{CO}_{3}$ (O) buffer, was preincubated at $37^{\circ} \mathrm{C}$ for $1 \mathrm{hr}$. After adjustment of the $\mathrm{pH}$ to 8.4 , the residual activity was measured. 
temperatures for $15 \mathrm{~min}$, the remaining enzyme activity was assayed. As shown in Fig. 5, bilirubin oxidase was stable up to $37^{\circ} \mathrm{C}$, but above $37^{\circ} \mathrm{C}$ gradual inactivation occurred. As shown in Fig. 6, bilirubin oxidase was stable in the $\mathrm{pH}$ range of 5.0 to $9.7 \mathrm{for} 60 \mathrm{~min}$ at $37^{\circ} \mathrm{C}$. When the enzyme solution was preserved at $5^{\circ} \mathrm{C}$ for 5 days, the enzyme was unstable below $\mathrm{pH} 9.0$ but stable in the range of $\mathrm{pH} 9.2$ to 9.7 .

\section{Effect of temperature and $\mathrm{pH}$ on the enzyme activity}

As shown in Fig. 7, the optimum temperature for the enzyme reaction was about $40^{\circ} \mathrm{C}$. Bilirubin is not dissolved in acid solution, so the effect of $\mathrm{pH}$ on the enzyme activity was investigated on the alkaline side. As shown in Fig. 8, the better $\mathrm{pH}$ for the enzyme reaction was about $\mathrm{pH} 8.0$.

\section{$\mathrm{Km}$ value}

From the Lineweaver-Burk plot inserted in Fig. 9, the apparent $\mathrm{Km}$ value for bilirubin

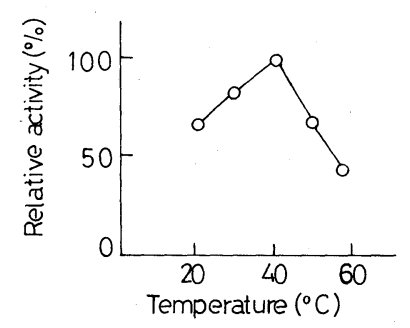

FIG. 7. Effect of Temperature on Activity.

The enzyme activity was measured at $\mathrm{pH} 8.4$ at various temperatures.

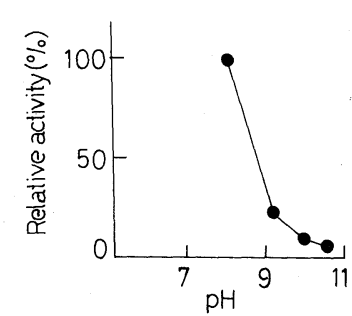

FIG. 8. Effect of $\mathrm{pH}$ on Activity.

The enzyme activity was measured with $0.1 \mathrm{M}$ buffer as indicated. $\mathrm{KH}_{2} \mathrm{PO}_{4}-\mathrm{Na}_{2} \mathrm{~B}_{4} \mathrm{O}_{7}$ buffer was used from $\mathrm{pH} 8.0$ to $9.2, \mathrm{Na}_{2} \mathrm{CO}_{3}-\mathrm{NaHCO}_{3}$ buffer from $\mathrm{pH} 9.2$ to 10 and $\mathrm{Na}_{2} \mathrm{~B}_{4} \mathrm{O}_{7}-\mathrm{Na}_{2} \mathrm{CO}_{3}$ buffer from $\mathrm{pH} 10$ to 10.5 . was calculated to be $190 \mu \mathrm{M}$.

\section{Substrate specificity}

Substances consisting of tetrapyrrole and substrates of laccase were tested for their reactivity against bilirubin oxidase. Laccase of Polyporus versicolor was tested in the same way. As shown in Table II, bilirubin was

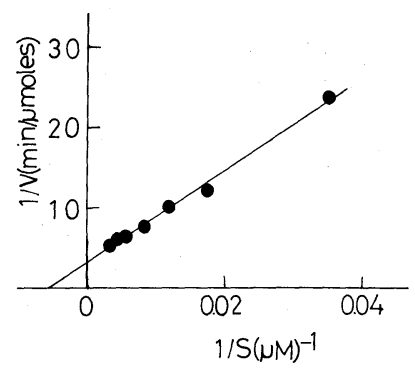

FIG. 9. Lineweaver-Burk Plots of Bilirubin Oxidase.

The enzyme activity was determined under the standard assay conditions.

Table II. SubStrate Specificity of Bilirubin OxidASE AND LACCASE

Manometric experiments were performed to determine the amount of molecular oxygen. The rate of oxidation of each substrate by bilirubin oxidase is expressed relative to the rate of bilirubin oxidation $(100 \%)$ and the rate of oxidation by laccase is expressed relative to the rate of $p$ phenylenediamine oxidation $(100 \%)$. Bilirubin oxidase

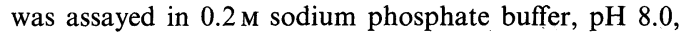
and laccase in $0.2 \mathrm{M}$ triethylamine-acetic acid buffer, $\mathrm{pH}$ 5.6. Bilirubin, biliverdin and hemin are dissolved only on the alkaline side, so these substances were assayed in $0.2 \mathrm{M}$ sodium phosphate buffer, $\mathrm{pH} 8.0$.

\begin{tabular}{|c|c|c|}
\hline \multirow{2}{*}{ Substrate } & \multicolumn{2}{|c|}{ Relative activity $(\%)$} \\
\hline & Bilirubin oxidase & Laccase \\
\hline Bilirubin & 100 & $\pm^{a}$ \\
\hline Biliverdin & 50 & $\pm^{a}$ \\
\hline Chlorophyllin & 50 & $\pm^{a}$ \\
\hline Hemin & 10 & $\pm^{a}$ \\
\hline Vitamin $\mathbf{B}_{12}$ & 0 & 0 \\
\hline Hemoglobin & 0 & 0 \\
\hline Hydroquinone & 20 & 100 \\
\hline Catechol & 67 & 83 \\
\hline Pyrogallol & 10 & 58 \\
\hline $\begin{array}{l}N, N \text {-Dimethyl-p- } \\
\text { phenylenediamine }\end{array}$ & 23 & 54 \\
\hline$p$-Phenylenediamine & 15 & 100 \\
\hline
\end{tabular}

a Oxidized only a little. 
Table III. EfFect of Metal Ions and Compounds That Complex WITH COPPER ON THE ENZYME ACTIVITY

The enzyme was preincubated for $10 \mathrm{~min}$ with the metal ion or compounds that complex with copper before the addition of substrate.

\begin{tabular}{lc}
\hline \multicolumn{1}{c}{ Compound $(1 \mathrm{~mm})$} & Relative activity $(\%)$ \\
\hline $\mathrm{None}$ & 100 \\
$\mathrm{Mn}^{2+}$ & 100 \\
$\mathrm{Cd}^{2+}$ & 100 \\
$\mathrm{Sr}^{2+}$ & 100 \\
$\mathrm{Cu}^{2+}(0.1 \mathrm{~mm})$ & 100 \\
$\mathrm{Fe}^{2+}$ & 0 \\
$\mathrm{Ni}^{2+}$ & 100 \\
$\mathrm{Mg}^{2+}$ & 100 \\
$\mathrm{Ca}^{2+}$ & 100 \\
$\mathrm{Li}^{2+}$ & 100 \\
Potassium cyanide $(0.1 \mathrm{~mm})$ & 0 \\
Sodium azide $(0.1 \mathrm{~mm})$ & 58 \\
Thiourea $(0.1 \mathrm{~mm})$ & 85 \\
\end{tabular}

oxidized more rapidly than other substances by bilirubin oxidase. Bilirubin oxidase differed from laccase in reactivity with substances consisting of tetrapyrrole. That is to say, substances which consisted of tetrapyrrole were oxidized only a little by laccase but rapidly oxidized by bilirubin oxidase.

\section{Effect of metal ions and compounds that com-} plex with copper on the enzyme activity

The effect of metal ions and compounds that complex with copper on the enzyme activity were examined. After preincubation of the enzyme with each reagent for $10 \mathrm{~min}$ at $30^{\circ} \mathrm{C}$, the remaining activity was determined (Table III). The enzyme activity was inhibited by $\mathrm{Fe}^{2+}$, potassium cyanide, sodium azide and thiourea.

\section{DISCUSSION}

From 3 liters of culture filtrate of
Myrothecium verrucaria MT-1, bilirubin oxidase was purified. The purified enzyme was homogeneous on disc gel electrophoresis and contained copper and carbohydrate. This enzyme was inhibited by $\mathrm{Fe}^{2+}$ and compounds that complex with copper. Biliverdin, hemin and chlorophyllin which consist of tetrapyrrole, and substrates of laccase were oxidized. Bilirubin was oxidized more rapidly than other substances. Bilirubin oxidase differed from laccase in reactivity with substances consisting tetrapyrrole. Substances consisting of tetrapyrrole were oxidized only a little by laccase but rapidly oxidized by bilirubin oxidase.

The presence of bilirubin oxidase activity was expected in the brain of guinea pig, but the pure enzyme was not obtained. ${ }^{10)}$ Therefore, the properties of bilirubin oxidase were not clear. But we purified bilirubin oxidase produced by Myrothecium verrucaria MT-1 and described the properties of the bilirubin oxidase.

Acknowledgment. The authors wish to thank Mr. T. Inukai for his valuable advice.

\section{REFERENCES}

1) S. Murao and N. Tanaka, Agric. Biol. Chem., 45, 2383 (1981).

2) S. Murao and N. Tanaka, Agric. Biol: Chem., 46, 2031 (1982).

3) B. J. Davis, Ann. N.Y. Acad. Sci., 121, 404 (1964).

4) R. M. Zacharius, T. E. Zell, T. H. Morrison and J. J. Woodlock, Anal. Biochem., 30, 148 (1969).

5) O. Vesterberg and H. Svensson, Acta Chem. Scand., 20, 820 (1966).

6) P. Andrews, Biochem. J., 96, 595 (1965).

7) S. Moore, J. Biol. Chem., 238, 235 (1963).

8) T. W. Goodwin and R. A. Morton, Biochem. J., 40, 628 (1964).

9) F. Fåhraeus and B. Reinhammar, Acta Chem. Scand., 21, 2367 (1967).

10) R. Brodersen and P. Bartels, Eur. J. Biochem., 10, 468 (1969). 